\title{
The Effects of the Wall Colors Used in Educational Spaces on the Perceptual Evaluations of Students
}

\author{
Eğitim Mekânlarında Kullanılan Duvar Renginin Öğrencilerin \\ Algısal Değerlendirmeleri Üzerindeki Etkileri
}

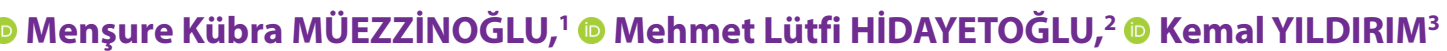

\section{ABSTRACT}

In this study, it was aimed to determine the perceptual quality of three design studios (warm, cool and neutral) that have different monochromatic color combinations on walls, but with the same characteristic attributes. In the study, real and controllable spaces were used for developing "individual productivity", "social adaptation" and "spatial quality" of the students positively, providing spatial belonging and increasing satisfaction. With this objective, a "spatial evaluation survey" was implemented on 113 students for testing the hypotheses and the data obtained were analyzed with the SPSS program. In conclusion, the warm and cool colored spaces were affected by the students more positively in the "spatial quality" evaluations compared to the neutral colored space and it was determined that the cool colored space had a positive effect on the subjects in the evaluations of the "social adaptation" and "individual productivity" scales.

Keywords: Design; educational spaces; spatial quality; wall color.

ÖZ

Bu çalışmada, aynı karakteristik özelliklerde, fakat duvarlarında farklı monokromatik renk kombinasyonları kullanılan (sıcak, soğuk ve nötr) üç adet tasarım stüdyosunun algısal kalitesinin belirlenmesi amaçlanmıştır. Çalışmada, öğrencilerin 'bireysel verimlilik', 'sosyal uyum' ve 'mekân kalitesi algısı' değerlendirmelerinin olumlu yönde geliştirilmesi, mekân aidiyetlerinin sağlanması ve memnuniyetlerinin arttırılması için gerçek ve kontrol edilebilir mekânlar kullanılmıştır. Bu maksatla oluşturulan hipotezleri test etmek için 113 öğrenciye "mekânsal değerlendirme anketi" uygulanmış olup, elde edilen veriler SPSS programı ile analiz edilmiştir. Sonuçta, sıcak ve soğuk renkli mekânların nötr renkli mekâna oranla öğrencilerin 'mekânsal kalite' değerlendirmelerini daha pozitif yönde etkilediği, soğuk renkli mekânın deneklerin 'sosyal uyum' ve 'bireysel verimlilik' ölçekleri değerlendirmeleri üzerinde pozitif yönde bir etkiye sahip olduğu tespit edilmiştir.

Anahtar sözcükler: Tasarım; eğitim mekânları; mekânsal algı; duvar rengi.

'Department of Interior Architecture and Enviromental Design, Selçuk University Faculty of Fine Arts, Konya, Turkey ${ }^{2}$ Department of Industrial Design, Selçuk University Faculty of Fine Arts, Konya, Turkey

${ }^{3}$ Department of Woodworking Industrial Engineering, Gazi University Faculty of Technology, Ankara, Turkey

Article arrival date: May 10, 2019 - Accepted for publication: January 03, 2020

Correspondence: Menşure Kübra MÜEZZiNOĞLU. e-mail: kubramzzn@selcuk.edu.tr

๑ 2020 Yıldız Teknik Üniversitesi Mimarlık Fakültesi - ๑ 2020 Yıldız Technical University, Faculty of Architecture 


\section{Introduction}

The United Nations Population Fund (UNFPA) reported that as of 2017, the world's population reached 7.6 billion people. ${ }^{1}$ More than $1 / 3$ of these 7.6 billion people are students / trainees in various fields. These results indicate that more than 2.5 billion people use educational spaces. This is an important point to be taken into consideration by managers, investors, entrepreneurs, planners and designers. Numerous studies have been designed to determine the characteristics of educational spaces where a significant portion of the world's population has spent most of their daily lives. ${ }^{2,3}$ However, it is not known sufficiently how students perceive design studios with different wall colors using monochromatic color combinations.

There exists a large body of literature on how the physical environment influences students' perception and behavior in educational spaces. Baker ${ }^{4}$ has emphasized physical environmental factors, classified as ambient factors (temperature, noise, scent, music and lighting), design factors (architecture, color, materials, pattern, texture and layout of the office) and social factors (consumers and employees). The proper use of environmental factors positively affects the perceptions, behaviors and spatial orientation of employees. Today, studies on educational space designs are still being carried out intensely..$^{5-17}$ Students spend a large part of their time in the educational spaces where they study. ${ }^{18}$ Therefore, it is of great importance to explore in detail the factors affecting the perceptual quality of these educational spaces and the ways of improving them. This study examines students' perceptions of environmental factors in design studios, especially, with emphasis on the effects of different wall colors using monochromatic color combinations. The findings of this study will add to what is now the interest of many researchers in studying the effect of environmental factors on educational space design.

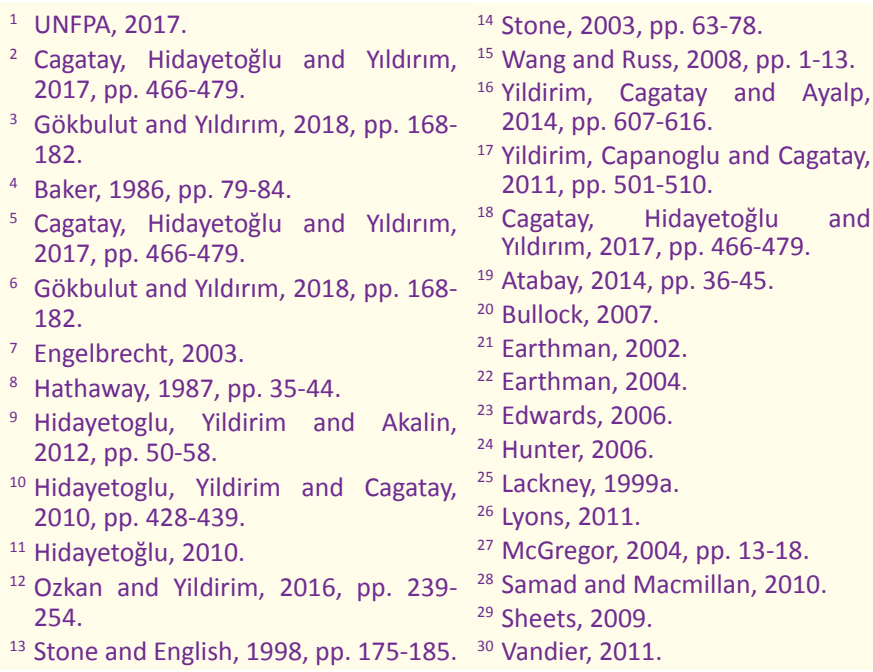

\section{Theoretical Background and Hypothesis Development}

Educational spaces are defined in many studies ${ }^{19-30}$ as places for physical, mental, psychological and social development of the students and it is expected that the development from these structures would be realized in an effective manner. Since the use of conscious color in the space is important in the formation of healthy environments, color should be thought of as a design element in the perception of spaces and a conscious use should be provided with the correct color information. When the educational spaces are planned at the optimum level, then it provides for contributions to the positive developments of the students and in this manner, the architectural design details, which provide the opportunity for active learning, experimentation, discovery, research, thought, producing, interrogating and socialization comes into the forefront. In this study, the positive evaluations by the students of educational spaces from the physiological, psychological and social aspects, to provide for spatial relations and to increase satisfaction for visual perception of the wall color organization attributes were researched by taking them within a whole. The findings obtained could be a guide for an increase in the level of quality and for the formation of educational spaces that could be used productively and that would be perceived as comfortable.

It has been shown in the literature studies related to color that classroom wall color could have positive and/ or negative influences on the behaviors and learning performances of students. Of these, it was stated in the studies by Engelbrecht ${ }^{31}$ and Hathaway ${ }^{32}$ that the mental stimulus obtained passively with the color of the classroom assists students and teachers in focusing on their duties. Many studies on this subject seem to focus especially on red and blue colors. ${ }^{33}$ This intensive interest could stem from the fact that red and blue colors are composed of two of the three main colors and furthermore, while red color has long waves, blue color has short waves..$^{34}$ In some research studies it has been expressed that blue color increases the duty performance of users compared to red and that spaces made colorful with blue color are quieter and make one feel better. ${ }^{35-37}$ There are research studies that set forth the opposite of this situation..$^{38}$ For example, in the study by Kwallekand Lewis, ${ }^{39}$ it was stated that in an environment where employees worked in which the color red (Munsell colour notation 6.05R 4.59/11.15) was dominant made fewer mistakes compared to those working in an environment in

\footnotetext{
${ }^{31}$ Engelbrecht, 2003.

${ }^{32}$ Hathaway, 1987, pp. 35-44. $\quad{ }^{36}$ Elliot and Aarts, 2011, pp. 445-449.

${ }^{33}$ Mehta and Zhu, 2009, pp. 1226- ${ }^{37}$ Zhang and Han, 2014.

1229.

${ }^{34}$ Xia, Song, Wang, Tan and Mo, 2016, Meinhardt, 2007, pp. 154-168.

pp. $784 . \quad{ }^{39}$ Kwallek and Lewis, 1990, pp. $275-$

${ }^{35}$ Stone and English, 1998, pp. 175- 278.
} 
which the color white was dominant. In another study, while fulfilling a low demand duty (making a written record based on voice recordings), it was reported that the performances of the participants in the red (Munsell colour notation $5 R 5 / 8$ ) environment were better than those in the blue (Munsell colour notation $10 \mathrm{~B} 7 / 6$ ) environment. ${ }^{40}$ However, in some studies, it was set forth that red weakened the performance on intellectual duties. ${ }^{41-44}$

In the study by Nelson, Pelech and Foster ${ }^{45}$ with the objective of determining which wave length colors were preferred in the preference of colors by people who were extroverts and introverts, it was observed that persons who had an impulse to high activity preferred red and persons who had an impulse to low activity preferred blue. ${ }^{46}$ In the study by Mehta and $\mathrm{Zhu}^{47}$ using various tasks covering several different domains, they demonstrated that red (HSL color notation $0,240,120$ ) (versus blue $-160,240,120$ ) can activate an avoidance (versus approach) motivation and subsequently, can enhance performance on detail-oriented (versus creative) cognitive tasks. Results from this research suggest that, depending on the nature of the task, different colors might be beneficial. If the task on hand requires people's vigilant attention (e.g., memorizing important information or understanding the side effects of a new drug), then red (or another color that activates an avoidance motivation) might be particularly appropriate. However, if the task calls for creativity and imagination (e.g., designing an art shop, or a new product idea brainstorming session), then blue (or another color that activates an approach motivation) would be more beneficial.

In the study by Camgoz, Yener and Guvenc ${ }^{48}$ that examined the effects on the attention of users for color tone, satisfaction and brightness, it was stated that in situations where the colors were the brightest and most satisfactory, it also increased their attractiveness. It was stated in the study that the most attractive colors were yellow, green and turquoise and that red and purple came later. In the studies by Wang and Russ, ${ }^{49}$ it was claimed that the cool colors in the Master Palette Color System were preferred more compared to the other colors for the wall colors in a computer classroom. Furthermore, in the study by Moore, McCarty and Jelin, ${ }^{50}$ it was emphasized that the use of warm color tones would be appropriate to use for creating a quieter environment. On the other hand, Old ${ }^{51}$ proposed the use of

\footnotetext{
${ }^{40}$ Stone, 2003, pp. 63-78.

${ }^{46}$ Grangaard, 1993.

${ }^{41}$ Elliot, Maier, Moller, Friedman and ${ }^{47}$ Mehta and Zhu, 2009, pp. 1226 Meinhardt, 2007, pp. 154-168.

${ }^{42}$ Shi, Zhang and Jiang, 2015, pp. 81- ${ }^{48}$ Camgoz, Yener and Guvenc, 2004, 84.

${ }^{43}$ Soldat, Sinclair and Mark, 1997, pp. 55-71. pp. 20-28.

${ }^{44}$ Thorstenson, 2015, pp. 306-311. $\quad{ }^{50}$ Moore, McCarty and Jelin, 1995

${ }^{45}$ Nelson, Pelech and Foster, 1984, pp. 913-914.

pp. 1-24.

${ }^{51}$ Olds, 1989, pp. 8-16.
}

warm tones for controlling the movement in moving areas and the use of cool tones for quiet and calming areas.

In the study by Read, Sugawara and Brandt ${ }^{52}$ they determined that the wall colors of the classrooms strengthened the cooperative behaviors of the students. Whereas, in the study by Hamid and Newport ${ }^{53}$ that examined pink and blue colored spaces, they reported that the mental statuses of the students were more positive in warm colored spaces. In the study by Hidayetoglu, ${ }^{54}$ it was stated that warm colors had an attractive feature and ability to be remembered and were higher compared to the other colors. In the study by Yildirim, Cagatay and Ayalp, ${ }^{55}$ it was claimed that blue classrooms were perceived more positively compared to cream and pink classrooms by male students and furthermore, classrooms with different colors were evaluated by being perceived as more positive by students. In the study by Cagatay, Hidayetoglu and Yildirim ${ }^{56}$ of school corridors in which different colors were used, it was stated that the cream colored corridors were perceived more positively compared to blue and green colored corridors.

As it can be observed from above, in the studies made related to "color", the subjects were studied in detail mostly on the psychological effects of colors, liking of the users, and on the effects on the productivity of the space by the conscious use of color in spaces. According to this, the effect of color on the perception of design studios formed in real environments will be examined in this study and it will be tested by statistical methods on whether there is a significant effect of wall color on the perception of space. The research hypotheses created within this scope are given below.

$\mathrm{H} 1$. The warm colors used in the design studios positively affected the evaluations of "spatial quality" by the students.

$H 2$. The cool colors used in the design studios positively affected the evaluations of "individual productivity" by the students.

H3. The cool colors used in the design studios positively affected the evaluations of "social adaptation" by the students.

Since the environmental data and the perception of these data covers a very extensive area, it is impossible to research by taking into consideration all the environmental factors together, to set forth certain design and application rules and to determine the limitations. In this study, as it was also stated above, only the color factor of the environmental variables was taken into the scope of the research study. Since it was necessary to keep the work

\footnotetext{
52 Read, Sugawara and Brandt, 1999, ${ }^{55}$ Yildirim, Cagatay and Ayalp, 2014, pp. 413-428. pp. 607-616.

${ }^{53}$ Hamid and Newport, 1989, pp. ${ }^{56}$ Cagatay, Hidayetoglu and Yildirim, 179-185.

${ }^{54}$ Hidayetoglu, 2010.
} 
Table 1. The tests groups used in the experiments

\begin{tabular}{lccc}
\hline Test groups & Year & \multicolumn{2}{c}{ Gender } \\
\cline { 3 - 4 } & & Female & Male \\
\hline Students receiving design education & $4^{\text {th }}$ year & 29 & 30 \\
Students not receiving design education & $4^{\text {th }}$ year & 27 & 27 \\
Total & & 113 Participants \\
\hline
\end{tabular}

scope of the study within certain limitations for the reliability of the research study made, the increase in the combinations of variables, such as the sound, texture, etc. and other internal space environmental factors were excluded from the scope of this study.

\section{Method}

\section{Participants}

A total of 120 subjects, 60 female and 60 male students studying at Selcuk University were included in the experiment to test the research hypotheses. The questionnaire filled in by 7 of these students were excluded from the evaluation because they were not reliable in the pre-control. The distribution of participants by gender and the departments in which they studied has been given in Table 1.

\section{Design of the Questionnaire}

Based on the research hypotheses, dependent variables were evaluated in one dimension and measured with a detailed questionnaire. The questionnaire form used consisted of two parts: the first part asked for general information, such as age, gender and visual defects of the students. The second part consisted of the semantic differential scale, which measures students' moods about the perceptual evaluations of the design studios. Moods are subjective experiences and, therefore, must be measured through self-report. Many questionnaires have been developed to measure perceptional evaluations. ${ }^{57}$ Some of the measures that have been widely used in research include the semantic differential scales developed by Nowlis, ${ }^{58}$ McNair, Lorr and Droppleman, ${ }^{59}$ Imamoglu, ${ }^{60}$ Curran and Cattell ${ }^{61}$ and Zuckerman and Lubin. ${ }^{62}$ Many measures of mood employ some form of the semantic differential developed by Osgood, Suci and Tannenbaum. ${ }^{63}$ The semantic differential consists of pairs of bipolar adjectives, or adjectives that are opposites of each other. For example, good / bad or pleasant / unpleasant are typical pairs of bipolar adjectives. ${ }^{64}$

\footnotetext{
57 McAndrew, 1993.

${ }^{58}$ Nowlis, 1965.

132.

${ }_{59}$ McNair, Lorr and Droppleman, 1971.

62 Zuckerman and Lubin, 1985.

Io Imamoglu, 1975.

63 Osgood, Suci and Tannenbaum, 1957.

${ }^{64}$ McAndrew, 1993.

${ }^{61}$ Curran and Cattell, 1976, pp. 113-
}

The students then had to evaluate the importance of each of the bipolar adjective pairs on a 1-7 semantic differential scale where $1=$ roomy and $7=$ cramped. A total of fifteen bipolar adjective pairs were evaluated by the students after familiarizing themselves with the items, five of which dealt with spatial quality, five with social adaptation, while the rest measured individual productivity. The Likert-type scales for spatial quality (warm/cool, light/dark, stimulating/drowsy, inviting/uninviting, roomy/cramped), social adaptation (facilitates communication/prevents communication, sincere/formal, relaxing/disagreeable, encouraging/pacifying, open to cooperation/closed to cooperation) and individual productivity (motivating/ boring, provides concentration/disrupts concentration, peaceful/unpeaceful, useful/useless, open to creativity/ closed to creativity) were used. The technique of altering the sets of items from positive to negative, as previously done by Imamoglu, ${ }^{65}$ Osgood, Suci and Tannenbaum, ${ }^{66}$ Berlyne, ${ }^{67}$ Erturk, ${ }^{68}$ Hidayetoglu, Yildirim and Akalin ${ }^{69}$ and Yildirim, Hidayetoglu and Capanoglu, ${ }^{70}$ Yildirim, Cagatay and Ayalp, ${ }^{71}$ Yildirim, Akalin and Hidayetoglu, ${ }^{72}$ Yildirim, Akalin-Baskaya and Hidayetoglu, ${ }^{73}$ Yildirim, Capanoglu, Cagatay and Hidayetoglu, ${ }^{74}$ Yildirim, Capanoglu and Cagatay $^{75}$ was adopted to reduce the probability of respondents simply marking the scale on either end of the extremes.

\section{Research Environment and Procedure}

It was necessary to prepare real and controllable spaces to be able to determine the effect on perception of space for the color element included within the physical environmental factors, for the participants to be able to experience different color variables and for being able to realize the experiment made in a sound manner. With this objective, three each design studios located at the Selcuk

\footnotetext{
${ }^{65}$ Imamoglu, 1975.

pp. 607-616

${ }^{66}$ Osgood, Suci and Tannenbaum, ${ }^{72}$ Yildirim, Akalin and Hidayetoglu, 1957.

${ }^{67}$ Berlyne, 1974.

${ }^{68}$ Erturk, 1983. 2007, pp. 33-40.

${ }^{73}$ Yildirim, Akalin-Baskaya and $\mathrm{Hi}-$ dayetoglu, 2007, pp. 3233-3240.

${ }^{69}$ Hidayetoglu, Yildirim and Akalin, ${ }^{74}$ Yildirim, Capanoglu, Cagatay and 2012, pp. 50-58.

Hidayetoglu, 2012, pp. 51-63.

${ }^{70}$ Yildirim, Hidayetoglu and Ca- ${ }^{75}$ Yildirim, Capanoglu and Cagatay, panoglu, 2011, pp. 509-524. 2011, pp. 501-510.
} 

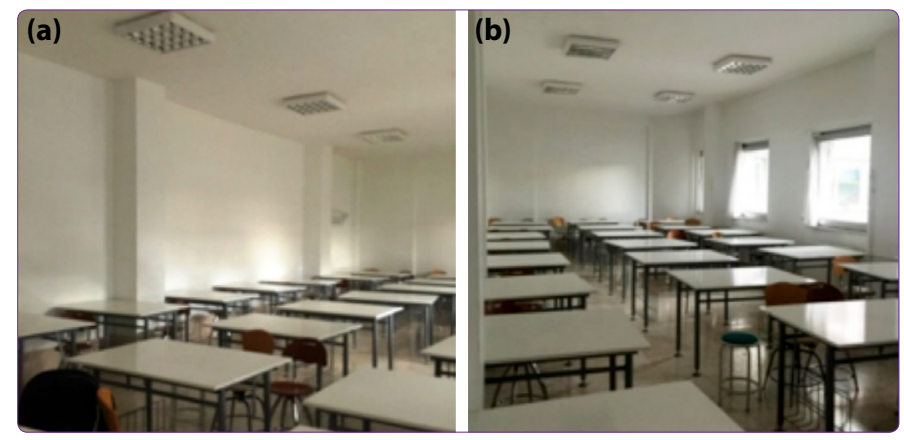

Figure 1. The existing conditions at the educational spaces prior to the experiment; (a) left view, (b) right view.

University, School of Fine Arts building and having an area of approximately $60 \mathrm{~m}^{2}$ were selected as the experimental environment to be used at the experimental stage. All the physical attributes at these design studios determined were kept under control by fixing all the physical attributes excluding the color elements, which would be evaluated as independent variables. The existing conditions of the educational spaces selected and located in the visuals given above were observed prior to making the organization (Figure 1). These spaces were transformed into the experimental environment with the color variables determined prior to the experiments.

The 113 subjects receiving education at the Selcuk University were shown six different monochromatic color combinations selected from the Jotun brand paint catalog observed in Table 2 and it was requested that they evaluate them according to the seven-step "warm and cool" adjective pairs for the seven-step color combinations in order to determine objectively the warm, cool and neutral monochromatic colors that would be applied on the walls of the experimental spaces.

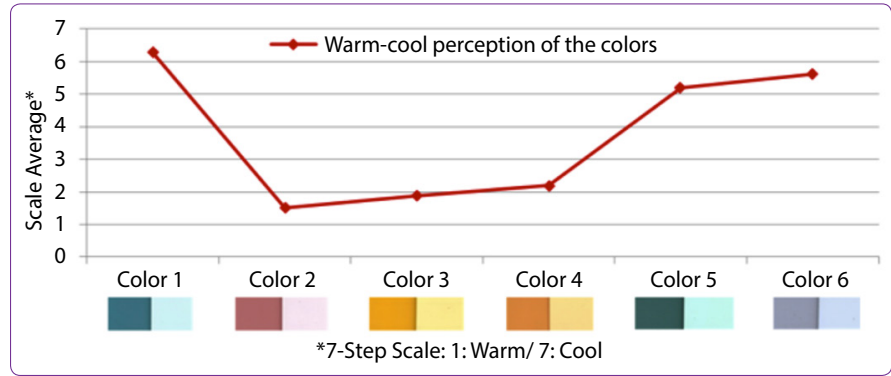

Figure 2. The evaluations by the subjects of the monochromatic color combinations.

The evaluations by the subjects of the monochromatic color combinations in the analysis that formed the first stage of the survey have been given in Figure 2.

According to Figure 2, the subjects perceived the blue colored combination observed in Color 1 , from among the colors shown to them, to be cooler compared to the other colors. Whereas, they perceived the red colored combination observed in Color 2 to be warmer compared to the other colors. Consequently, it was decided to form for the representation of the cool color of the colors that would be used in the research study the NCS S 0515-B and S 3040-B10G combination. Whereas, it was decided to form for the representation of the warm color of the colors the NCS S 0515-R40B and S 2040-Y95R combination. Whereas, the NCS S 0500-N color was used for the neutral color (Table 3).

After the stage of determining the warm and cool colors that would be used for the real space experiment, the walls of the design studios that would be used for the experiments were painted with the combined colors selected, as observed in the visuals, with the objective of increasing the color emphasis (Figure 3).

Table 2. The monochromatic color combinations that were requested to be evaluated

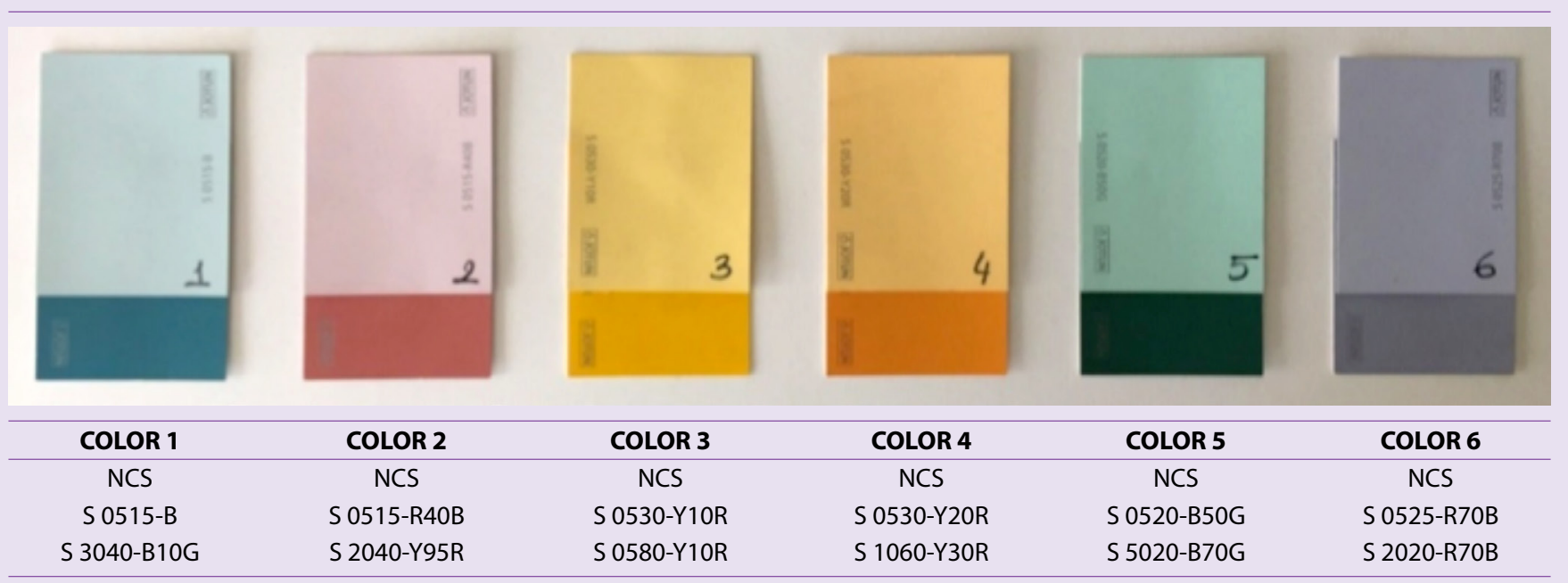

NCS: Natural Color System 

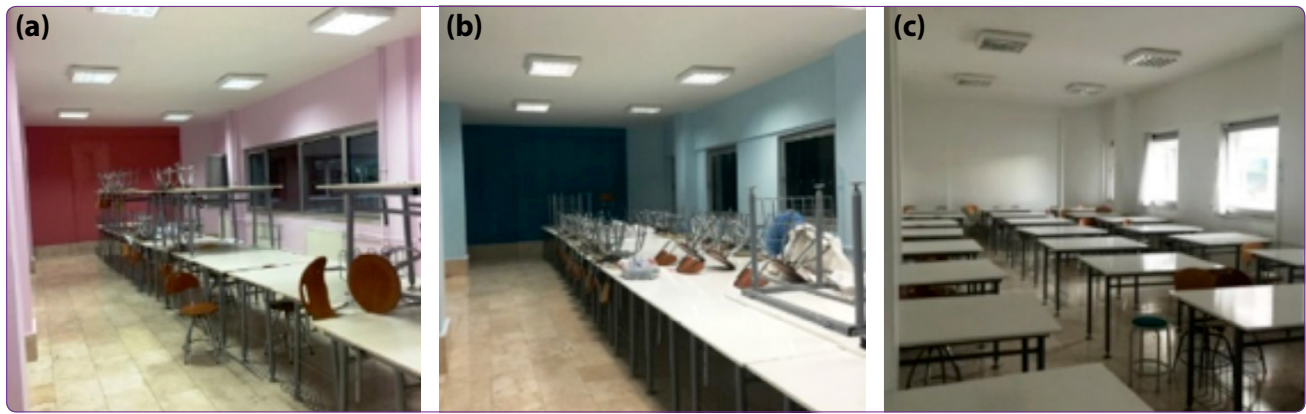

Figure 3. Preparation of the experimental environment for the (a) warm, (b) cool and (c) neutral colors.
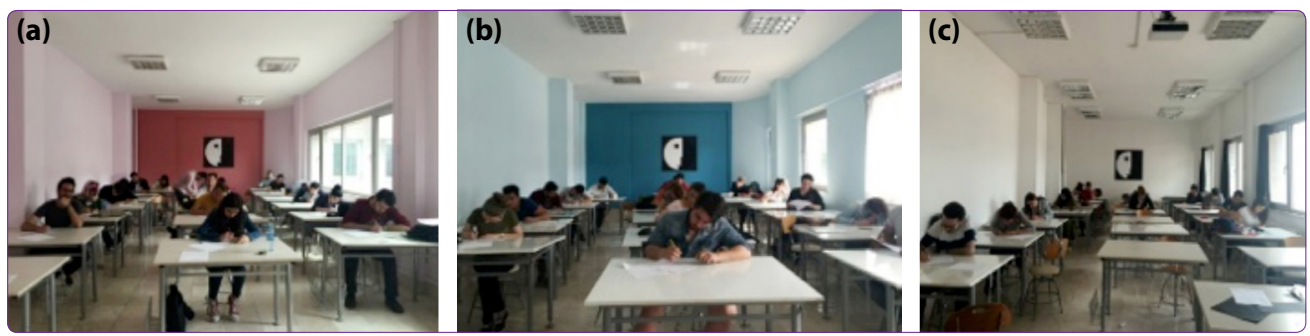

Figure 4. Experimental stage of the spaces painted with (a) warm, (b) cool and (c) neutral colors.

\section{Application and Procedure of Experiments}

At this stage of the experiment, it made use of a subject group of 59 persons who received design education and of 54 persons who did not receive design education for a total of 113 persons was used. The environments where the experiments were realized the design studios painted with the warm, cool and neutral colors, respectively. After taking the subject group into the space up to the capacity of the design studio and after an approximately 10-minute briefing, it was requested from the subjects that they respond to the research study survey given to them for testing the hypotheses of the study (Figure 4). This stage of the experiment was realized in a period of approximately 20 minutes for each color and group.

\section{Statistical Evaluation}

The effects on the perceptual evaluations of the students were examined in this study for different wall colors used in the design studios. Accordingly, the evaluations of the students for the wall colors of the design studios were accepted as dependent variables, whereas, the wall color was accepted as an independent variable. The SPSS package program was used in the evaluation of research data. The percentage values, arithmetic averages and standard deviation values of the data obtained in the study were calculated, the Cronbach's Alpha reliability tests of the data were made and finally, the statistical aspect of the differences between the dependent and independent variables were tested with the one-way analysis of variance (ANOVA) technique on whether they were statistically significant at a level of $p<0.05$. The Tukey's Honest Significant Difference (HSD) Test was made for being able to compare with each other the variables found to be significant in the ANOVA and the data were shown graphically for being able to compare the averages of the variables with each other.

\section{Results}

It was aimed in this study to reach information

Table 3. The RGB and NCS values of the colors used in the experiments

\begin{tabular}{lll}
\hline Colors & & Color Codes \\
\cline { 2 - 3 } & Red, Green, Blue Color System & Natural Color System \\
\hline Warm Color (Red) & Light 255/228/225 & S 0515-R40B \\
\hline Cool Color (Blue) & Dark 220/20/60 & S 2040-Y95R \\
\hline Light 198/226/255 & S 0515-B \\
\hline Dark 27/139/180 & S 3040-B10G \\
\hline
\end{tabular}


Table 4. Cronbach's alpha reliability analysis results

\begin{tabular}{lll} 
Scale group & Adjective pairs & Scale reliability \\
\hline Spatial quality & Warm / Cool, Light / Dark, Stimulating / Drowsy, Inviting / Uninviting, Roomy / Cramped & 0.752 \\
Social adaptation & $\begin{array}{l}\text { Facilitates communication / Prevents communication, Sincere / Formal, Relaxing / } \\
\text { Disagreeable, Encouraging / Pacifying, Open to cooperation / Closed to cooperation }\end{array}$ & 0.821 \\
Individual productivity & $\begin{array}{l}\text { Motivating / Boring, Provides concentration / Disrupts concentration, Peaceful / } \\
\text { Unpeaceful, Useful / Useless, Open to creativity / Closed to creativity }\end{array}$ & 0.923 \\
& & 0.880
\end{tabular}

Note: The reliability of each scale given in the table is ensured.

Table 5. The average, standard deviation and Tukey's HSD test results of the adjective pairs formed for the spatial quality scale connected to wall color

\begin{tabular}{|c|c|c|c|c|c|c|c|c|c|c|c|c|}
\hline \multirow[t]{3}{*}{ Spatial quality scale } & \multicolumn{9}{|c|}{ Wall colors of design studios } & \multicolumn{3}{|c|}{ ANOVA results } \\
\hline & \multicolumn{3}{|c|}{ Warm } & \multicolumn{3}{|c|}{ Cool } & \multicolumn{3}{|c|}{ Neutral } & \multirow[b]{2}{*}{$\mathbf{F}$} & \multirow[b]{2}{*}{ df } & \multirow[b]{2}{*}{ Sig. } \\
\hline & M & SD & HG & $\mathbf{M}$ & SD & HG & $\mathbf{M}$ & SD & HG & & & \\
\hline Warm / Cool & $2.35 a$ & 1.446 & $A$ & 4.53 & 1.914 & B & 4.82 & 1.560 & B & 75.904 & 2 & $0.000^{*}$ \\
\hline Light / Dark & 2.94 & 1.447 & $A$ & 2.76 & 1.683 & $A$ & 2.62 & 1.687 & A & 1.113 & 2 & 0.330is \\
\hline Stimulating / Drowsy & 3.09 & 1.550 & $A$ & 2.92 & 1.717 & $A$ & 3.86 & 1.822 & B & 9.781 & 2 & $0.000^{*}$ \\
\hline Inviting / Uninviting & 3.15 & 1.702 & $A$ & 2.95 & 1.679 & $A$ & 4.31 & 1.701 & B & 21.280 & 2 & $0.000^{*}$ \\
\hline Roomy / Cramped & 3.01 & 1.765 & $A$ & 2.51 & 1.513 & $A$ & 3.78 & 1.720 & B & 16.483 & 2 & $0.000^{*}$ \\
\hline
\end{tabular}

Note: Tukey's HSD: The differences among the homogeneous groups are significant at the level of ${ }^{*} \mathrm{p}<0.05$.

M: Average value, SD: Standard deviation, HG: Homogeneous group, F: F value, df: Degree of freedom, Sig.: Insignificant. a: Variable averages have been listed from 1 to 7 . A high value shows negative responses.

that would assist designers in designing perceptibly high-quality spaces. With this purpose, the effects of different wall colors used in design studios for developing the evaluations of the spatial quality scale, social adaptation scale and individual productivity scale of students positively and for increasing the conditions of comfort and satisfaction were studied. As a sample, design studios located at the Selcuk University, School of Fine Arts building were selected. The data obtained from the selected places were tested by statistical methods and the results obtained have been given below in a systematic order.

The reliability of the data obtained from this study was tested with the Cronbach's Alpha Test and the results have been given in Table 4. According to the results of the Cronbach's Alpha reliability analysis, it was determined that the reliability coefficient of the spatial quality scale, which includes the color evaluations, was 0.75 , the social adaptation scale was 0.82 , whereas, the individual productivity scale was 0.88 . In the studies made previously by Cronbach, ${ }^{76}$ McKinley, Manku-Scott, Hastings, French and Baker, ${ }^{77}$ Kaplan and Saccuzzo ${ }^{78}$ and Panayides, ${ }^{79}$ it

\footnotetext{
${ }^{76}$ Cronbach, 1951, pp. 297-334. 198.

77 McKinley, Manku-Scott, Hastings, ${ }^{78}$ Kaplan and Saccuzzo, 2009.

French and Baker, 1997, pp. 193- ${ }^{79}$ Panayides, 2013, pp. 687-696.
}

was reported that when the alpha reliability coefficients for all elements is above 0.70 , then it could be accepted to be "reliable". It was observed that the Cronbach alpha coefficients obtained in this study were above the specified value. Accordingly, the data obtained can be accepted to be "reliable".

Here, the research hypotheses mentioned in the previous sections and analyzes for these hypotheses will be made. Firstly, the categorical averages, standard deviation values and the Tukey's HSD test results for the data obtained for the effects on the perceptual evaluations of the students according to the spatial quality of the colors used in the design studios have been given in Table 5 .

It was observed in Table 5 that there were statistically significant differences among the perceptual evaluations of the students according to the spatial quality scale for the wall colors used in the design studios for the adjective pairs of "warm/cool" ( $F=75.904, d f=2, p=0.000)$, "stimulating/ drowsy" ( $F=9.781, d f=2, p=0.000)$, "inviting/uninviting" $(\mathrm{F}=21.280, \mathrm{df}=2, \mathrm{p}=0.000)$ and "roomy/cramped" ( $\mathrm{F}=$ 16.483, $d f=2, p=0.000)$. However, for the "light/dark" $(\mathrm{F}=1.113, \mathrm{df}=2, \mathrm{p}=0.330)$ adjective pair a statistically significant difference was not found at the level of $p<0.05$. According to the Tukey's HSD test, when comparing the warm colored space with other cool and neutral colored 


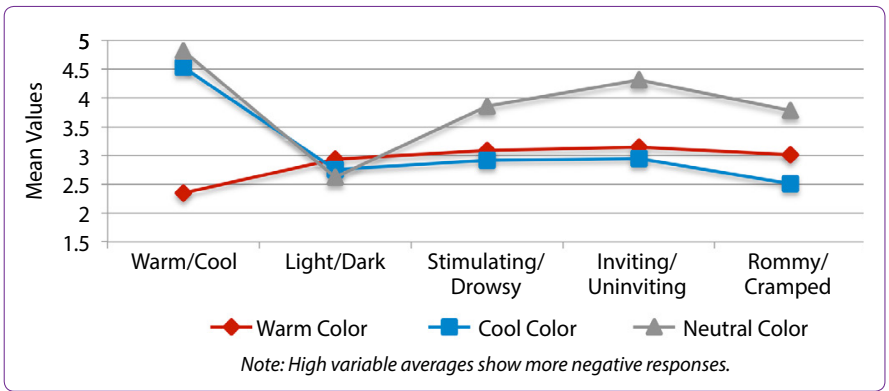

Figure 5. Evaluation of different colored studios according to the spatial quality scale.

spaces for a warm/cool adjective pair, it was observed that there were statistically significant differences between the group mean values of the warm colored space with the cool and neutral colored spaces at the level of $p<0.05$. In conclusion, it can be stated that the three different colors used in the design studios had significant effects on the perceptual evaluations of the students according to the spatial quality scale. The graphical expression of these results has been given in Figure 5 .

According to Figure 5, it was observed that the average values of the spaces with warm and cool colors were very close to each other for the other adjective pairs except for the warm/cool adjective pair. Also, the average values of the spaces having the warm, cool and neutral wall colors were rather close to each other for the "light/ dark" adjective pair. It was understood from the figure that the cool colored space was perceived as "roomier", "stimulating" and "inviting" compared to the warm colored space. This result did not support the H1 hypothesis, which asserts "The warm colors used in the design studios positively affected the evaluations of 'spatial quality' by the students". According to these results, it can be said that the spaces where both warm and cool monochromatic

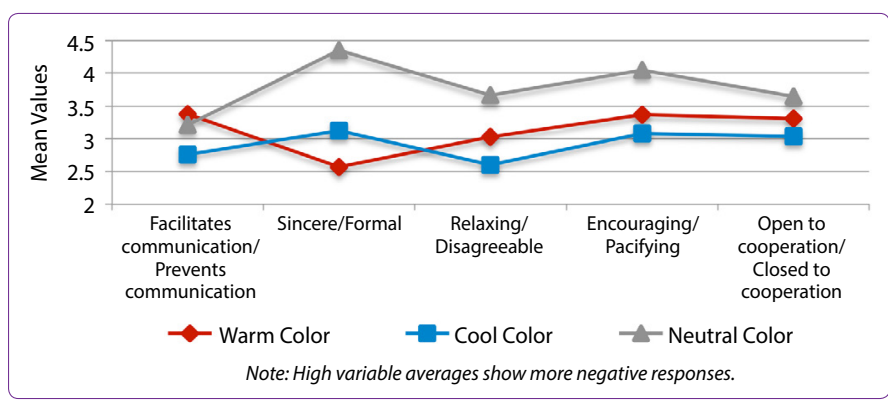

Figure 6. Evaluation of different colored studios according to the social adaptation scale.

color combinations were used affected the evaluations of spatial quality by the subjects more positively than the neutral color space.

On the other hand, the categorical averages, standard deviation values and the Tukey's HSD test results of the data obtained for the effects on the perceptual evaluations by the students according to the social adaptation scale for the colors used in the design studios have been given in Table 6 .

It was observed in Table 6 that there were statistically significant differences among the perceptual evaluations by the students according to the social adaptation scale for the wall colors used in the design studios for the adjective pairs of "facilitates communication/prevents communication" ( $\mathrm{F}=4.744, \mathrm{df}=2, \mathrm{p}=0.008)$, "sincere/ formal" ( $F=31.859, d f=2, p=0.000)$, "relaxing/disagreeable" $(\mathrm{F}=11.525, \quad \mathrm{df}=2, \quad \mathrm{p}=0.000)$, "encouraging/pacifying" $(F=9.377, d f=2, p=0.000)$ and "open to cooperation/closed to cooperation" ( $F=4.178, d f=2, p=0.016)$. In conclusion, it can be stated that the three different colors used in the design studios had significant effects on the perceptual evaluations by the students according to the social adaptation scale. The graphical expression of these results has been given in Figure 6 .

Table 6. The average, standard deviation and the Tukey's HSD results of the elements forming the social adaptation scale connected to wall color

\begin{tabular}{|c|c|c|c|c|c|c|c|c|c|c|c|c|}
\hline \multirow[t]{3}{*}{ Social adaptation scale } & \multicolumn{9}{|c|}{ Wall colors of design studios } & \multicolumn{3}{|c|}{ ANOVA results } \\
\hline & \multicolumn{3}{|c|}{ Warm } & \multicolumn{3}{|c|}{ Cool } & \multicolumn{3}{|c|}{ Neutral } & \multirow[b]{2}{*}{$\mathbf{F}$} & \multirow[b]{2}{*}{ df } & \multirow[b]{2}{*}{ Sig. } \\
\hline & $\mathbf{M}$ & SD & HG & $\mathbf{M}$ & SD & HG & $\mathbf{M}$ & SD & HG & & & \\
\hline Facilitates Communication & $3.38 \mathrm{a}$ & 1.54 & B & 2.76 & 1.51 & A & 3.21 & 1.63 & $A-B$ & 4.774 & 2 & $0.008^{*}$ \\
\hline \multicolumn{13}{|l|}{ / Prevents Communication } \\
\hline Sincere / Formal & 2.57 & 1.61 & $A$ & 3.12 & 1.76 & B & 4.35 & 1.77 & $\mathrm{C}$ & 31.859 & 2 & $0.000^{*}$ \\
\hline Relaxing / Disagreeable & 3.03 & 1.71 & $A$ & 2.60 & 1.59 & A & 3.66 & 1.71 & B & 11.525 & 2 & $0.000^{*}$ \\
\hline Encouraging / Pacifying & 3.37 & 1.80 & A & 3.08 & 1.73 & A & 4.05 & 1.66 & B & 9.377 & 2 & $0.000^{*}$ \\
\hline Open to Cooperation / & 3.31 & 1.51 & $A-B$ & 3.04 & 1.53 & $A$ & 3.65 & 1.79 & B & 4.178 & 2 & $0.016^{*}$ \\
\hline
\end{tabular}

Closed to Cooperation

Note: Tukey's HSD: The differences among the homogeneous groups are significant at the level of * $p<0.05$.

M: Average value, SD: Standard deviation, HG: Homogeneous group, F: F value, df: Degree of freedom, Sig.: insignificant. a: Variable averages have been listed from 1 to 7 . A

high value shows negative responses. 
Table 7. The averages, standard deviations and Tukey's HSD test results of the elements formed by the individual productivity scale connected to wall color

\begin{tabular}{|c|c|c|c|c|c|c|c|c|c|c|c|c|}
\hline \multirow{3}{*}{$\begin{array}{l}\text { Individual productivity } \\
\text { scale }\end{array}$} & \multicolumn{9}{|c|}{ Wall colors of design studios } & \multicolumn{3}{|c|}{ ANOVA results } \\
\hline & \multicolumn{3}{|c|}{ Warm } & \multicolumn{3}{|c|}{ Cool } & \multicolumn{3}{|c|}{ Neutral } & \multirow[b]{2}{*}{$\mathbf{F}$} & \multirow[b]{2}{*}{ df } & \multirow[b]{2}{*}{ Sig. } \\
\hline & M & SD & HG & $\mathbf{M}$ & SD & HG & M & SD & HG & & & \\
\hline Motivating / Boring & $3.07 a$ & 1.66 & A & 2.70 & 1.57 & A & 3.96 & 1.75 & B & 17.051 & 2 & $0.000^{*}$ \\
\hline $\begin{array}{l}\text { Provides concentration / } \\
\text { Disrupts concentration }\end{array}$ & 3.58 & 1.72 & B & 2.73 & 1.60 & A & 3.19 & 1.82 & $A-B$ & 6.932 & 2 & $0.001^{*}$ \\
\hline Peaceful / Unpeaceful & 2.76 & 1.60 & A & 2.37 & 1.54 & A & 3.54 & 1.79 & B & 14.744 & 2 & $0.000^{*}$ \\
\hline Useful / Useless & 3.20 & 1.63 & B & 2.56 & 1.54 & A & 3.32 & 1.92 & B & 6.542 & 2 & $0.002^{*}$ \\
\hline $\begin{array}{l}\text { Open to creativity / } \\
\text { Closed to creativity }\end{array}$ & 3.10 & 1.89 & A & 2.77 & 1.68 & A & 4.12 & 1.93 & B & 16.454 & 2 & $0.000^{*}$ \\
\hline
\end{tabular}

Note: Tukey's HSD: The differences among the homogeneous groups are significant at the level of ${ }^{*} p<0.05$.

M: Average value, SD: Standard deviation, HG: Homogeneous group, F: F value, df: Degree of freedom, Sig.: insignificant. a: Variable averages have been listed from 1 to 7 . A high value shows negative responses.

It was observed in Figure 6 that the cool colored space was evaluated more positively compared to the neutral and warm colored spaces for social adaptation. However, the warm colored space was perceived as sincerer compared to the cool and neutral colored spaces. When it was considered as of the results in general, the "social adaptation" evaluations of the cool colored spaces by the test subjects had a more positive effect. This result supports the $\mathrm{H} 2$ hypothesis, which claims, "The cool colors used in the design studios positively affected the 'social adaptation' evaluations by the students". According to these results, it can be said that the cool colored spaces have a more positive effect on the "social adaptation" assessments by the subjects.

Lastly, the categorical averages, standard deviation values and the Tukey's HSD test results of the data obtained for the effects on the perceptual evaluations of the students according to the "individual productivity" scale of the colors used in the design studios have been given in Table 7.

It was observed in Table 7 that there were statistically significant differences among the perceptual evaluations by the students according to the individual productivity scale for the wall colors used in the design studios for the adjective pairs of "motivating/boring" ( $F=17.051$, $\mathrm{df}=2, \quad \mathrm{p}=0.000)$, "provides concentration/disrupts concentration" ( $F=6.932, d f=2, p=0.001)$, "peaceful/ unpeaceful" ( $F=14.744, d f=2, p=0.000)$, "useful/useless" ( $F=6.542, d f=2, p=0.002$ ) and "open to creativity/closed to creativity" ( $F=16.454, d f=2, p=0.000)$. In conclusion, it can be clearly observed that there were significant effects on the perceptual evaluations by the students according to the individual productivity scale. The graphical expression of these results has been given in Figure 7 .

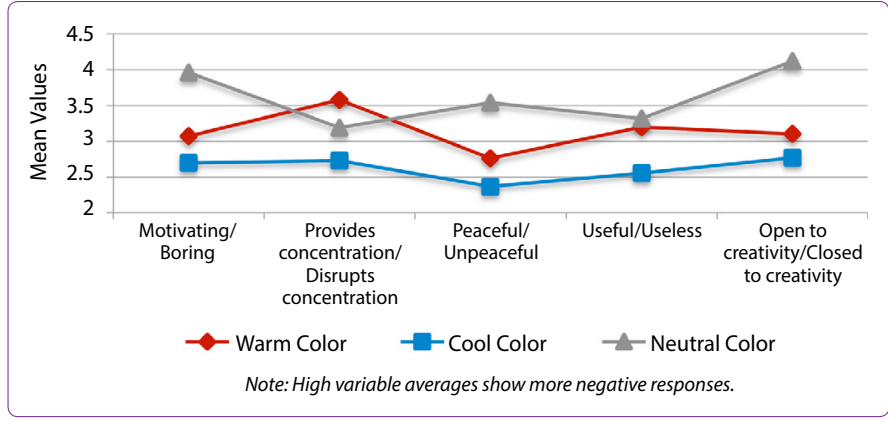

Figure 7. Evaluation of different colored studios according to the individual productivity scale.

As it can be observed in Figure 7, while the cool colored space was evaluated more positively compared to the other spaces for the individual productivity scale, the neutral colored space was evaluated more negatively compared to the other spaces. It is understood from the figure that the cool colored space was found to be more "motivating" and "peaceful" compared to the other spaces. This result supports the $\mathrm{H} 3$ hypothesis, which asserts, "The cool colors used in the design studios positively affected the individual productivity' evaluations by the students". Accordingly, it can be stated that the cool colored space had a positive effect on the evaluations by the students on the individual productivity scale.

\section{Conclusions and Suggestions}

Many studies have been made for being able to determine the physical attributes of educational spaces where a significant portion of the world population spends a majority of its daily life. ${ }^{80-93}$ However, an

\footnotetext{
${ }^{80}$ Cagatay, Hidayetoğlu and Yıldırım, ${ }^{81}$ Gökbulut and Yıldıım, 2018, pp. 2017, pp. 466-479. 168-182.
} 
insufficient number of studies were encountered for how the educational spaces, which were designed by using monochromatic color combinations, were perceived by students. In this study, the attributes of the color organizations used in educational spaces were researched for the positive development in "individual productivity", "social adaptation" and "spatial quality" evaluations, of the students, for providing spatial relations and for increasing satisfaction were researched and the conclusions were treated in a systematic order given below.

In the first evaluation, the effects were determined on the perceptual evaluations of the students for the three different design studios in which monochromatic color combinations were used. Accordingly, it was observed in a clear manner that the students participating in the study perceived the space where the walls were painted with a warm color (RGB color notation 255/228/225 and $220 / 20 / 60$ ) as "warmer" compared to the spaces painted with neutral or cool colors. Furthermore, both the cool colored space and the warm colored space were perceived as more "motivating", "inviting" and "roomier" compared to the neutral colored space. This result did not support the (H1) hypothesis, "The warm colors used in the design studios positively affected the evaluations of 'spatial quality' by the students," which was formed by benefiting from the studies by Hidayetoglu, ${ }^{94}$ Stone and English, ${ }^{95}$ Kaya and Crosby, ${ }^{96}$ Levy ${ }^{97}$ and Uludag and Odaci. ${ }^{98}$ These results obtained showed that for the "motivating", "inviting" and "roomy" components, that cool colors, just like the warm colors, positively affected the "spatial quality" evaluations for the design studios compared to the neutral colors. According to these results, it can be proposed that chromatic colors should be used instead of achromatic colors in the design of educational spaces for them to be perceived more positively by students and for forming better impressions.

Furthermore, in the study the effects on the "social adaptation" performances of the students in three different design studios used in monochromatic color combinations were determined. Accordingly, it was observed that the students who participated in the research study perceived the walls of the spaces painted with cool colors (RGB color notation 198/226/255 and 27/139/180) to "facilitate communication", "relaxing", "encouraging" and "open

\footnotetext{
82 Engelbrecht, 2003.

${ }^{83}$ Hathaway, 1987, pp. 35-44.

${ }^{84}$ Hidayetoğlu, 2010.

${ }^{85}$ Yildirim, Capanoglu and Cagatay, 2011, pp. 501-510.

${ }^{86}$ Earthman, 2002.

${ }^{87}$ Edwards, 2006.

${ }^{88}$ Mehta and Zhu, 2009, pp. 12261229.

${ }^{89}$ Zhang and Han, 2014.

${ }^{90}$ Grangaard, 1993.
}

to communication" compared to the walls of the spaces painted with neutral and warm colors. Furthermore, it was observed that the walls of the spaces painted with neutral color (RGB color notation 242/242/242) were evaluated more negatively compared to the spaces painted with warm and cool colors from the aspect of "social adaptation". This result, supports the ( $\mathrm{H} 2)$ hypothesis, "The cool colors used in the design studios positively affected the 'individual productivity' evaluations by the students," which was formed by benefiting from the studies of Hidayetoglu, ${ }^{99}$ Stone and English, ${ }^{100}$ Yıldırım, Akalin-Baskaya and Hidayetoglu, ${ }^{101}$ Frieling ${ }^{102}$ and Kaya and Crosby. ${ }^{103}$ It can be stated from the data obtained that the cool colored spaces had a more positive effect on the "social adaptation" evaluations by the subjects. According to these results, in the courses where intra-group activities would be made, in environments where the dialogue between educator and students would be high, in the spaces where face-to-face talks would be realized, in interactive courses and in situations where it is aimed to raise "social adaptations" to a higher level, then it could be proposed to use cool colors in the design of educational spaces.

Finally, in the study, the effects were determined on the "individual productivity" performances by the students of the three different design studios where monochromatic color combinations were used. Accordingly, it was observed that the students who participated in the research study perceived the spaces where the walls were painted with cool colors (RGB color notation 198/226/255 and 27/139/180) to be more "motivating", "provides concentration", "peaceful", "useful" and "open to creativity" compared to the spaces painted with warm or neutral colors. Furthermore, it was observed that the walls of the spaces painted with neutral color were evaluated more negatively compared to the spaces with warm or cool colors from the aspect of "individual productivity". This result supports the (H3) hypothesis, "The cool colors used in the design studios positively affected the 'individual productivity' evaluations of the students," formed by benefiting from the studies by Hidayetoglu, ${ }^{104}$ Stone, ${ }^{105}$ Yildirim, Akalin and Hidayetoglu ${ }^{106}$ and Kaya and Crosby. ${ }^{107}$ According to the results obtained, it can be stated that the evaluations on the "individual productivity" scale by the subjects for the cool colored space had a positive effect. In situations where it is aimed to raise to a higher level the "individual productivities" within the space of the individuals using the educational spaces, then it could be proposed that cool colors should be used in the design of the spaces.

\footnotetext{
99 Hidayetoglu, 2010.

${ }^{103}$ Kaya and Crosby, 2006, pp. 67-71.

100 Stone and English, 1998, pp. 175- ${ }^{104}$ Hidayetoglu, 2010. 185.

105 Stone, 2003, pp. 63-78.

101 Yıldırım, Akalin-Baskaya and Hi- 106 Yildirim, Akalin and Hidayetoglu, dayetoglu, 2007, pp. 3233-3240.

102 Frieling, 1979. 2007, pp. 33-40.

107 Kaya and Crosby, 2002, pp. 67-71.
} 
This study was limited to the design studios at the university level and to a color combination of three different monochromatic colors in order to be able to determine the effects of the variables. In subsequent research, new studies could be made on other environmental factors, such as heat, acoustics, noise and light as well as at other levels of education-instruction, such as kindergartens, primary schools and high schools.

\section{Acknowledgements}

The authors would like to thank both Ellen Andrea Yazar for her careful translation and proofreading of the English text and the valuable design students who participated in the survey study.

\section{References}

Atabay, S. (2014) "Mekân ve mimarinin eğitimde başarıya etkisi", In: Binat B. and Şık N. (eds.), Eğitim Yapıları Vitra Çağdaş Mimarlık Dizisi 3, Istanbul: Literatür Yayınları, pp. 36-45.

Baker, J. (1986) "The role of the environment in marketing services: the consumer perspective", In: Czepeil, J.A., Congram, C.A. and Shanahan, J. (eds.), Integrating for Competitive Advantage, Chicago, IL: American Marketing Association, pp. 79-84.

Berlyne, D.E. (1974) Studies in the New Experimental Aesthetics, Wiley: New York, NY.

Bullock, C. (2007) "The Relationship Between School Building Condition and Student Achievement in Virginia Middle Schools", Ph.D. Thesis, Virginia Polytechnic Institute and State University, VA.

Cagatay, K., Hidayetoğlu, M.L. and Yıldırım, K. (2017) "Lise koridor duvarlarında kullanılan renklerin öğrencilerin algısal değerlendirmeleri üzerindeki etkileri", H.U. Journal of Education, 32 (2), pp. 466-479.

Camgoz, N., Yener, C. and Guvenc, D. (2004) "Effects of hue, saturation, and brightness: Part 2: Attention", Color Res. Appl., 29 (1), pp. 20-28.

Cronbach, L.J. (1951) "Coefficient alpha and the internal structure of tests", Psychometrika, 16 (3), pp. 297-334.

Curran, J.P. and Cattell, R.B. (1976) Manual for the eight state questionnaire, Multivar. Exp. Clin. Res., 7, pp. 113-132.

Edwards, N.C. (2006) "School Facilities and Student Achievement: Student Perspectives on the Connection Between the Urban Learning Environment and Student Motivation and Performance", Ph.D. Thesis, Philosophy Department of the Ohio State University, $\mathrm{OH}$.

Elliot, A.J. and Aarts, H. (2011) "Perception of the color red enhances the force and velocity of motor output", Emotion, 11 (2), pp. 445-449.

Elliot, A.J., Maier, M.A., Moller, A.C. (2007) "Friedman R and Meinhardt J. Color and psychological functioning: the effect of red on performance attainment", J. Exp. Psychol. Gen., 136 (1), pp. 154-168.

Engelbrecht, K. (2003) "The Impact of Color on Learning", Chicago, IL: Perkins \& Will.

Ertürk, S. (1983) “Mimari mekânların algılanması üzerine deneysel bir çalışma", Ph.D. Thesis, Black Sea Technical University, Turkey.
Frieling, H. (1979) "Farbe im raum", Angewandte Farbenpsychologie, Munich, Germany: Callwey Verlag.

Gökbulut, N. and Yıldırım, K. (2018) “Tasarım stüdyolarında çizim masası yoğunluğunun öğrencilerin algısal performansı üzerindeki etkileri", Online J. Art Design, 6 (4), pp. 168-182.

Grangaard, E.M. (1993) "Effects of Color and Light on Selected Elementary Students", Ph.D. Thesis, Department of Educational Administration and Higher Education University of $\mathrm{Ne}-$ vada, Las Vegas, NV.

Hamid, P.N. and Newport, A.G. (1989) "Effect of colour on physical strength and mood in children", Percept. Motor Skill., 69 (1), pp. 179-185.

Hathaway, W.E. (1987) "Light, colour \& air quality: important elements of the learning environment", Educ. Canada, 27 (3), pp. 35-44.

Hidayetoglu, M.L., Yildirim, K. and Cagatay, K. (2010) "The effects of training and spatial experience on the perception of the interior of buildings with a high level of complexity", Sci. Res. Essays, 5 (5), pp. 428-439.

Hidayetoglu, M.L., Yildirim, K. and Akalin, A. (2012) "The effects of color and light on indoor wayfinding and the evaluation of the perceived environment", J. Environ. Psychol., 32 (1), pp. 50-58.

Hidayetoğlu, M.L. (2010) “Üniversite Eğitim Yapılarının Iç Mekânlarında Kullanılan Renk ve Işığın Mekânsal Algılama ve Yön Bulmaya Etkileri", Ph.D. Thesis, University of Gazi University, Turkey.

Hunter, M.A. (2006) "Public School Facilities: Providing Environments that Sustain Learning", Teachers College Columbia University, New York, NY: National Access Network.

Imamoglu, V. (1975) "Spaciousness of Interiors", Ph.D. Thesis, University of Strathclyde, Glasgow, Scotland.

Kaplan, R.M. and Saccuzzo, D.P. (2009) "Psychological Testing Principles", Applications, and Issues. Boston, MA: Cengage Learning.

Kaya, N. and Crosby, M. (2006) “Color associations with different building types: An experimental study on American college students", Color Res. Appl., 31 (1), pp. 67-71.

Kwallek, N. and Lewis, C.M. (1990) "Effects of environmental colour on males and females: a red or white or green office", Appl. Ergon., 21 (4), pp. 275-278.

Lackney, J.A. (1999a) "Assessing School Facilities for Learning/ Assessing the Impact of the Physical Environment on the Educational Process: Integrating Theoretical Issues with Practical Concerns", State Educational Design Institute, Mississippi State University, (ERIC Document Reproduction Service No. ED 441 330).

Lackney, J.A. (1999b) “Why Optimal Learning Environment Matters", State Educational Design Institute, Mississippi State University, Starkville, MS.

Levy, B.I. (1984) "Research into the psychological meaning of color", American Journal of Art Therapy, 23, pp. 58-62.

McAndrew, F.T. (1993) "Environmental Psychology", Belmont, CA: Brooks/Cole Publishing Company. Wadsworth, Inc.

McGregor, J. (2004) "Space, power and the classroom", Forum, 46 (1), pp. 13-18.

McKinley, R.K., Manku-Scott, T., Hastings, A.M., French, D.P. and Baker, R. (1997) "Reliability and validity of a new measure of 
patient satisfaction with out of hours primary medical care in the United Kingdom: development of a patient questionnaire", BMJ, 314 (7075), pp. 193-198.

McNair, D.M., Lorr, M. and Droppleman, L.F. (1971) "Manual for the Profile of Mood States", San Diego, CA: Educational and Industrial Testing Service.

Mehta, R. and Zhu, R.J. (2009) "Blue or red? Exploring the effect of color on cognitive task performances", Science, 323 (5918), pp. 1226-1229.

Moore, G.T., McCarty, A.L. and Jelin, G. (1995) “Children's village: a safe haven for children of stress and violence", Child. Environ., 12 (1), pp. 1-24.

Müezzinoğlu, M.K. (2018) “Eğitim Mekânlarında Kullanılan Renk ve Işıgın Öğrencilerin Fonksiyonel ve Algısal Değerlendirmeleri Üzerindeki Etkileri", Ph.D. Thesis, Selcuk University, Institute of Science, Turkey.

Nelson, G.J., Pelech, M.T. and Foster, S.F. (1984) "Color preference and stimulation seeking", Percept. Motor Skill., 59 (3), pp. 913-914.

Nowlis, M. (1965) "Research with the mood adjective check list", In: Tomkins, S. S., \& Izard, C. E. (eds.), Affect, Cognition and Personality, New York: Springer-Verlag.

Olds, A.R. (1989) "Psychological and physiological harmony in child care center design”, Child. Environ. Q., 6 (4), pp. 8-16.

Osgood, C.E., Suci, G.J. and Tannenbaum, P.H. (1957) "The Measurement of Meaning", Urbana, IL: University of Illinois Press.

Ozkan, A. and Yildirim, K. (2016) "Comparison of conventional and computer-aided drafting methods from the view of time and drafting quality", Eurasian J. Educ. Res., 62, pp. 239-254.

Panayides, P. (2013) "Coefficient alpha: Interpret with caution", Eur. J. Psychol., 9 (4), pp. 687-696.

Read, M.A., Sugawara, A.I. and Brandt, J.A. (1999) "Impact of space and color in the physical environment on preschool children's cooperative behavior", Environ. Behav., 31 (3), pp. 413-428.

Sheets, M.E. (2009) "The Relationship Between the Condition of School Facilities and Certain Educational Outcomes, Particularly in Rural Public High Schools in Texas", Ph.D. Thesis, Texas Tech University, Lubbock, TX.

Shi, J., Zhang, C. and Jiang, F. (2015) "Does red undermine individuals' intellectual performance? A test in China", Int. J. Psychol., 50 (1), pp. 81-84.

Soldat, A.S., Sinclair, R.C. and Mark, M.M. (1997) "Color as an environmental processing cue: external affective cues can directly affect processing strategy without affecting mood", Soc. Cogn., 15 (1), pp. 55-71.

Stone, N.J. and English, A.J. (1998) "Task type, posters, and workspace color on mood, satisfaction and performance", J. Environ. Psychol., 18 (2), pp. 175-185.

Stone, N.J. (2003) "Environmental view and color for a simulated telemarketing task", J. Environ. Psychol., 23 (1), pp. 63-78.

Thorstenson, C.A. (2015) "Functional equivalence of the color red and enacted avoidance behavior? Replication and empirical integration", Soc. Psychol., 46 (5), pp. 306-311.

Uludag, Z. and Odaci, H. (2002) "Eğitim öğretim faaliyetlerinde fiziksel mekân”, Milli Eğitim Dergisi, 2002; Kış-Bahar Issue, pp. 153-154.

Vandier, B. (2011) "The Impact of School Facilities on the Learn- ing Environment", Ph.D. Thesis, Capella University, Minneapolis, MN.

Wang, H. and Russ, R.R. (2008) "Computer classroom wall colour preference and the relationship with personality type of college students", Colour: Design Creat., 2 (4), pp. 1-13.

Xia, T., Song, L., Wang, T.T., Tan, L. and Mo, L. (2016) “Exploring the effect of red and blue on cognitive task performances", Front. Psychol., 7, pp. 784., doi: 10.3389/fpsyg.2016.00784.

Yildirim, K. and Akalin-Baskaya. A. (2007) "Perceived crowding in a café-restaurant with different seating densities", Build. Environ., 42 (9), pp. 3410-3417.

Yildirim, K., Akalin, A. and Hidayetoglu, M.L. (2007) "The effects of the store window type on consumers' perception and shopping attitudes through the use of digital pictures", G.U. J. Sci., 20 (2), pp. 33-40.

Yildirim, K., Akalin-Baskaya, A. and Hidayetoglu, M.L. (2007) "Effects of indoor color on mood and cognitive performance", Build. Environ., 42 (9), pp. 3233-3240.

Yildirim, K., Cagatay, K. and Ayalp, N. (2014) "Effect of wall colour on the perception of classrooms", Indoor Built Environ., 24 (5), pp. 607-616.

Yildirim, K., Capanoglu, A. and Cagatay, K. (2011) "The Effects of physical environmental factors on students' perceptions in computer classrooms", Indoor Built Environ., 20 (5), pp. 501510.

Yildirim, K., Capanoglu, A., Cagatay, K. and Hidayetoglu, M.L. (2012) "Effect of wall colour on the perception of hairdressing salons", J. Int. Colour Assoc., 7, pp. 51-63.

Yildirim, K., Hidayetoglu, M.L. and Capanoglu, A. (2011) "Effects of interior colors on mood and preference: comparisons of two living rooms", Percept. Motor Skill., 112 (2), pp. 509-524.

Zhang, T. and Han, B. (2014) "Experience reverses the red effect among Chinese stockbrokers", PLoS ONE, 9 (2), e89193. doi: 10.1371/journal.pone.0089193.

Zuckerman, M. and Lubin, B. (1985) "Manual for the MAACL-R: The Multiple Affect Adjective Check List Revised", San Diego, CA: Educational and Industrial Testing Service.

\section{Internet References}

Earthman, G.I. (2004) "Prioritization of 31 Criteria for School Building Adequacy", Baltimore, MD: American Civil Liberties Union Foundation of Maryland. http://www.aclumd.org/ aTop\%20lssues/Education\%20Reform/EarthmanFinal10504. (accessed 16 March 2019).

Earthman, G.I. (2002) "School Facility Conditions and Student Academic Achievement", UCLA:'s Institute for Democracy, Education and Access. https://escholarship.org/uc/item/ 5sw56439. (accessed 16 March 2019).

Lyons, J.B. (2011) "Do School Facilities Really Impact a Child's Education?", Issue Trak: A CEFPI Brief on Educational Facility Issues, https://files.eric.ed.gov/fulltext/ED458791.pdf. (accessed 16 March 2019).

Samad, Z.A. and Macmillan, S. (2010) "The valuation of intangibles: explored through primary school design", http://www. irbnet.de/daten/iconda/CIB5532.pdf. (accessed 16 March 2019).

UNFPA Annual Report (2017) "www.unfpa.org/annual-report" (accessed 16 Mar 2019). 